\title{
EFFECTS OF ADDITION MICROBIAL INOCULANTS OR FORMIC ACID TO WHOLE CORN PLANT AT ENSILING ON SILAGE QUALITY, NUTRITIVE VALUE AND RUMEN FERMENTATION IN SHEEP AND MILK YIELD AND COMPOSITION OF LACTATION COWS. \\ Soliman. M. S. \\ Regional Centre for Food and Feed, Agricultural Research Centre, Ministry of Agricultur, Dokki, Egypt
}

\begin{abstract}
Whole corn plants at stage of maturity were treated by adding microbial inoculants or formic acid at ensiling to determine the effect of these additives (lactic acid bacterial inoculants (LAB) or formic acid) on the fermentation during ensiling. Nutrients digestion coefficients, nitrogen balance, rumen function and DM,CF degradability of sheep fed rations containing untreated or treated silage. Feed intake, milk production and milk composition of crossbred Friesian cows fed treated or untreated silage plus $6 \mathrm{~kg}$ CFM were also studied. The results of silage quality indicated that formic acid silage had lower $(\mathrm{P}<0.05)$ value of $\mathrm{pH}$, ammonia nitrogen, total VFA and lactic acid than inoculanted silage and untreated silage. The results of the chemical and physical characteristics indicated a good quality for the untreated or treated silages. Nine Barki meal sheep used in digestibility experiment were assigned into 3 similar groups of 3 each. Animals were fed one of experimental rations R1, R2 or control, which containing inoculanted silage, formic acid treated silage or un-treated silage respectively. The results showed insignificant differences $(P<0.05)$ in digestibility of $\mathrm{DM}$ and $\mathrm{OM}$ among experimental rations. Highest $(P<0.05) \mathrm{CP}$ digestibility and NB observed with ration containing formic acid silage. Moreover all animals fed experimental rations showed positive NB. While, highest $(P<0.05)$ CF digestibility was recorded for the ration containing inoculanted silage. However, nutritive value were significantly $(P<0.05)$ higher with $R 1$ and $R 2$ than control. Rumen fermentation and in-situ trails determined using three cannulated female Barki sheep. The main results showed that $\mathrm{NH}_{3}-\mathrm{N}$ concentration was higher for sheep given the control ration following $\mathrm{R} 1$. While, highest $(P<0.05)$ TVFA'S was recorded for sheep fed R1and R2 compared to those fed control ration. On the other hand, microbial protein synthesis was lowest $(P<0.05)$ for sheep fed R1 and R2 than those fed ration containing un-treated silage which recorded highest value. Dry matter and CF degradability showed significant $(P<0.05)$ increased for rations containing inoculants silage than control ration. Ration containing formic acid silage showed intermediate value. Feed intake, milk yield and milk composition were significantly increased for cows fed inoculants silage and formic acid silage. Also, these silage additives showed improved in Net revenue and Economic Efficiency\%. These results introduce a nove technique towards making best use of agricultural residues as a compensatory feed for feeding ruminants and minimize such problems of disposal pollution.
\end{abstract}

\section{INTRODUCTION}

Corn silage is a high-quality forage crop that is used in many dairy farms. Whole-plant corn is an ideal silage crop with adequate water-soluble carbohydrates for satisfactory fermentation to lactic acid McDonald et al., (1991). Recently corn silage had increased rapidly as green forage for ruminants. This increase is related to its relatively high energy content and as 
Soliman, M. S.

highly palatable quality forage Mohamed et al., (2003). About 4 and 0.6 million tons or corn stover and corn cobs are produced as co-products in Egypt annually (Central Administration of Agricultural Extension2010). This agricultural residue could be used to overcome partially the gab in problem of inadequate quantity of ruminant feeds. Various methods applied to increase the nutritional quality of agricultural by-products and silage one of these methods. Fermentation will occur until enough lactic acid is produced to drop the $\mathrm{pH}$ to approximately 4.2 , at which point all bacterial action stops. This usually occurs within three weeks after a silo is filled and it can be stored for long periods of time without losing quality. Bill Seglar (2003). Silage additives have been developed by Adesogan and Salawu, (2004); Adesogan et al., (2007). to improve the ensiling process, additives are advantageous because they are safe and easy to use, do not pollute the environment and are regarded as natural products. Bacterial inoculants are added to silage in order to stimulate lactic acid fermentation, accelerating the decrease in $\mathrm{pH}$, and thus improving silage preservation. Most available inoculants selected strains of homofermentative LAB, such as Lactobacillus plantarum, Pediococcus, and Enterococcus species, Weinberg et al., (1995). Addition of formic acid to silage material has been reported to have positive effects on fermentation Snyman and Joubert, (1996). Formic acid is commonly used as a preservative for direct-cut silage, when exposed to air Driehuis et al (2001). Formic acid has anti-bacterial effect on many bacterial species, is particularly effective at inhibiting the activity of undesirable bacteria, such as Clostridia and Enterobacteria; thereby, it may permit lactic acid bacteria to dominate the fermentation including LAB (O'Kiely, 1993; Randby, 1999). But a greater amount of water soluble carbohydrates (WSC) content of silage which is a better source of energy for rumen microorganisms than lactic acid Bosch et al., (1991). The aim of this study was to determine the effects of formic acid and bacterial inoculants on whole plant corn silage quality, digestion coefficient, nitrogen balance, ruminal fermentation characteristics in sheep and milk production of dairy cows. The impact of the silage additives on economic efficiency was also measured.

\section{MATERIALS AND METHODS}

The silage was made from fresh whole corn plant (WCS) which was collected from Noubaria region at the end of July 2013. The corn plants were chopped to a length $1-3 \mathrm{~cm}$, with approximately 32\% DM. (The same volume of water which was used to dissolve the silage additives was added to the control treatment to maintain equal moisture). Three treatments were used in this experiments, the control (untreated WCS), the second treatment was WCS + Bacterial inoculants (Pioneer brand 1174, Lactobacillus plantarum) added at the rate of $2 \times 10^{10}$ colony forming units (cfu)/g of fresh forage and the third was WCS + formic acid (Xilong Chemical company) added at the rate of 4 liter / ton fresh forage. The proximate chemical analysis of fresh whole corn plant (WCS) before ensiling and the concentrate feed mixture (CFM) used in this experiment are presented in Table (1). 
Table (1): Chemical analysis for fresh whole corn plant (WCS) and concentrate feed mixture (CFM):

\begin{tabular}{|c|c|c|c|c|c|c|c|c|c|c|c|c|}
\hline \multirow{2}{*}{ Item } & \multirow{2}{*}{ DM } & \multicolumn{11}{|c|}{ (On DM basis) } \\
\hline & & OM & CP & CF & EE & NEF & Ash & NDF & ADF & ADL & Hemicellulose & cellulose \\
\hline $\begin{array}{l}\text { WCP } \\
\text { fresh }\end{array}$ & 31.59 & 94.32 & 9.13 & 27.13 & 2.66 & 55.4 & 5.68 & 50.98 & 30.14 & 5.01 & 20.84 & 25.13 \\
\hline $\mathrm{CFM}^{*}$ & \begin{tabular}{|l|}
92.20 \\
\end{tabular} & 91.23 & 16.25 & 10.56 & 3.55 & 60.87 & 8.77 & 25.42 & 15.23 & 2.07 & 10.19 & 13.16 \\
\hline
\end{tabular}

Three stacks were covered separately by double-layers linoleum plastic, then covered by a layer of soil approximately $20 \mathrm{~cm} 2$ depth and straw bales to guarantee anaerobic condition. Samples from the three stacks were taken after 60 days to determine silage quality and chemical composition.

This work was conducted at Noubaria Experimental Station, Animal Production Research Institute, Agricultural Research Center, Ministry of Agriculture.

Silage quality:

For evaluating silage quality, silage extract was prepared by homogenizing 30 gram fresh material with $270 \mathrm{ml}$ distilled water then blended for 10 minutes in laboratory blender Waldo and Schultz, (1956). The homogenized sample was filtered through a Whatman No. 54 filter paper until it becomes perfectly clear. The $\mathrm{pH}$ value was directly determined using Orion 680 digital $\mathrm{pH}$ meter. Lactic acid concentration was evaluated by titration with $0.1 \mathrm{~N}$ sodium hydroxide solution using 3 drops of phenolphthalein as indicator, the $\mathrm{NaOH}$ was added until the colour changes to pink. Each millilitre of $\mathrm{NaOH}$ is equivalent to $90.08 \mathrm{mg}$ of lactic acid according to the AOAC (1990). Total volatile fatty acids (VFA'S) concentration was determined according to Warner (1964). Molar proportion of VFA'S (acetic, propionic and butyric) were measured according to Bush et al. (1979) using High Performance Liquid Chromatography (HPLC) Sample detection was by UV absorbance at $210 \mathrm{~nm}$. Ammonia nitrogen (NH3-N) concentration was determinate by direct distillation according to the AOAC (1990). Results concerning the quality of Silage samples are shown in Table 2.

Digestibility Trials:

Nine Barki male sheep (average live body weight $41 \mathrm{~kg} \pm 2.5$ ) was used in a completely randomized design digestibility experiment. They were distributed on to three equal groups and used in consecutive trials, three animals / group. The animals were fed 600-g DM / head / day from commercial concentrate feed mixture plus $1500 \mathrm{~g}$ from treated or untreated WCS calculated to cover their maintenance requirements according to (NRC, 1994). Chemical composition of the experimental rations (600g CFM plus $1500 \mathrm{WCS}$ ) are presented in table 3. Each digestibility trial lasted three weeks as preliminary period followed by one week as a collection period. The animals were housed in metabolic cages and beneath each, a stainless steel screen having $4 \mathrm{~mm}$ mesh to retain feces but allow free passage of urine, which was collected through a funnel containing $5-7 \mathrm{ml}$ sulfuric acid preservative to prevent the loss of nitrogen from the urine. The animals were 
Soliman, M. S.

fed one of the following experimental rations R1, R2 or control which containing inoculants silage, formic acid silage or untreated silage respectively, twice daily at 8.00 and 17.00 . Water was available all time. Feed samples were collected and prepared for proximate analysis. Feces and urine were collected quantitatively once a day before the morning meal at 8.00 , and stored at $-10^{\circ} \mathrm{C}$. The seven days combined collection was mixed the sampled and kept for routine analysis. Fecal samples were dried at $60^{\circ} \mathrm{C}$ for 72 hours (partial drying) and ground through a $1 \mathrm{~mm}$ screen on a Wiley mill grinder. They were composted $(20 \mathrm{gm})$ per sample per treatment per animal for analysis. Daily urine volume was measured and samples of $10 \%$ of the volume was taken in glass bottles and stored in a refrigerator for nitrogen determination. Digestibilities were determined and expressed on dry matter basis. Proximate analyses were carried out according to A.O.A.C. (1995), crude protein (CP) by Kjeldahl, while nitrogen free extract (NFE) was calculated by difference. Fiber fraction (NDF, ADF and ADL) was determined as described by Goering and Van Soest (1970).

\section{Rumen Fermentation Trials: -}

Three Barki female sheep fitted with permanent rumen fistula (with an average of $40 \mathrm{~kg} \pm 1.50$ live body weight) were used in rumen fermentation. The animals were fed the same rations used in the digestibility trials. Rumen contents were collected from the fistula at $0,1,3$ and 6 hours after feeding. Samples were flushed with $\mathrm{CO}_{2}$ during the collection time, and incubated at $39^{\circ} \mathrm{C}$ in thermostatically controlled water-bath. At zero time two sub-samples were poured into another jars containing formalin $(1 \mathrm{ml} / 100 \mathrm{~g}$ rumen contents) and swirled vigorously to stop metabolic activity. One of these samples was used to estimate concentration of ammonia and volatile fatty acid (VFA); the other one was used to determine the dry matter percentage in the rumen contents El-Shazly and Hungate, (1965). Rumen samples taken at zero and at one hour of fermentation were strained through cheesecloth. The supernatant was used for determination $\mathrm{pH}$ immediately using a glass electrode, ammonia nitrogen (mg/ $100 \mathrm{ml} \mathrm{R.L.)} \mathrm{using} \mathrm{(MgO)} \mathrm{distillation}$ method of Al-Rabbat et al., (1971). The total VFAs (m.eq/ $100 \mathrm{ml} \mathrm{R.L.)} \mathrm{were}$ estimated using steam distillation as described by Warner (1964). and molar percentages of major VFA (acetic, propionic and butyric) was carried out using HPLC.

The microbial protein (MP) synthesized in the rumen of sheep fed the experimental rations were calculated as g MP per day using, total bacteria count was carried out according to Russell (1984). In situ trials:

Two polyester bags (100\% Dacron polyester) with a mean pore size of $45 \mu \mathrm{m}$ and the bags $(7 \times 15 \mathrm{~cm})$ had a surface area of about $210 \mathrm{~cm}^{2}$ were used at each incubation time. Approximately $3 \mathrm{~g}$ of untreated silage, silage with inoculants or silage treated with formic acid were placed in each bag. The bags were incubated in the rumen of each sheep and removed after 2, 4, $6,8,12,24,48$ and 72 hour. After the removal of the bags, they were washed gently under a flowing steam of tap water until the fluid was clear. The bags were drained, dried at $60{ }^{\circ} \mathrm{C}$ for 72 hours. Dry matter and crude fiber content were determined according to the method of the A.O.A.C. (1995).Two bags 
were washed in running water for $15 \mathrm{~min}$. to determine the initial soluble fraction (a). The effective rumen degradability (ED) was calculated according to Orskov and McDonald (1979) equation ED $=a+b c / c+k$. where, $a, b$ and $c$ are estimates of soluble fraction, the degradable fraction and the rate of degradation, respectively. Rumen out flow rate $(k)$ was assumed to be 0.06 per hour (McDonald 1981).

Table (2):Chemical composition and silage quality of treated or untreated WCS silages (on DM basis).

\begin{tabular}{|c|c|c|c|}
\hline Item & $\begin{array}{l}\text { Untreated silage } \\
\text { Control }\end{array}$ & $\begin{array}{c}\text { Treated silage* } \\
\text { Bacterial } \\
\text { inoculants }\end{array}$ & $\begin{array}{l}\text { Treated silage }{ }^{\star \star} \\
\text { Formic acid }\end{array}$ \\
\hline DM & 29.13 & 29.97 & 31.06 \\
\hline OM & 93.39 & 93.27 & 93.85 \\
\hline $\mathrm{CP}$ & 8.28 & 8.62 & 8.97 \\
\hline CF & 26.33 & 25.71 & 26.04 \\
\hline EE & 2.54 & 2.65 & 2.41 \\
\hline NFE & 56.24 & 56.29 & 56.43 \\
\hline Ash & 6.61 & 6.73 & 6.15 \\
\hline NDF & 48.07 & 46.45 & 47.85 \\
\hline ADF & 28.55 & 26.37 & 28.05 \\
\hline ADL & 4.88 & 4.28 & 4.53 \\
\hline Hemi cellulose & 19.52 & 20.08 & 19.80 \\
\hline Cellulose & 23.67 & 22.09 & 23.52 \\
\hline \multicolumn{4}{|c|}{ Silage quality } \\
\hline $\mathrm{pH}$ & $3.85 \pm 0.04^{a}$ & $3.76 \pm 0.03^{a}$ & $3.64 \pm 0.03^{b}$ \\
\hline $\mathrm{NH}_{3}-\mathrm{N} \%$ of Total $\mathrm{N}$ & $9.04 \pm 0.15^{a}$ & $8.31 \pm 0.11^{\mathrm{ab}}$ & $7.05 \pm 0.18^{b}$ \\
\hline TVFA'S \% & $6.26 \pm 0.17^{\mathrm{ab}}$ & $6.64 \pm 0.13^{a}$ & $5.36 \pm 0.19^{b}$ \\
\hline Lactic acid \% DM & $4.11 \pm 0.06^{b}$ & $4.90 \pm 0.04^{\mathrm{a}}$ & $3.92 \pm 0.03^{c}$ \\
\hline Acetic acid \% DM & $1.5 \pm 0.01^{\mathrm{a}}$ & $1.4 \pm 0.01^{b}$ & $1.3 \pm 0.02^{c}$ \\
\hline Propionic acid \% DM & $0.6 \pm 0.003^{a}$ & $0.3 \pm 0.002^{b}$ & $0.1 \pm 0.002^{c}$ \\
\hline Butyric acid\% DM & 0.05 & 0.04 & 0.04 \\
\hline
\end{tabular}

abc Means within the same rows with different superscript are significantly differ $(\mathrm{P}<0.05)$.

*WCS silage treated with Bacterial inoculants, ${ }^{\star *}$ WCS silage treated with formic acid

\section{Lactation Trials:}

Nine lactating crossbred Friesian multiparous cows were chosen based on their milk production in the previous 4 weeks before calves; they had the same days in milk, lactation number and with an average live body weight (450 kg \pm 6.5 in average). used in this experiment studies. Each three cows were offered one of the experimental diets for 45 days of which the first 15 days was considered as preliminary period followed by 30 days collection period. The cows were fed to cover their maintenance requirement and requirement for the production. Maintenance requirement calculated according to (NRC, 1990) and requirement for the production were calculated from preliminary period and also the milk yield previous according to Barney Harris (1992). Cows were fed 6-kg CFM / head/ day plus one of the following 
Soliman, M. S.

silage with inoculants, formic acid silage or untreated silage ad-lib and offered fresh at 9.00 a.m. and 17.00 p.m. the cows were milked twice a day and milk samples ( $1 \%$ of milk yield/ period) were taken during the 30 days at 8.00 and 16.00. Actual milk yields were recorded daily and milk samples were taken and kept at $4{ }^{\circ} \mathrm{C}$ for analysis. Fat corrected milk (4\%) was calculated according to Gaines (1923) using the following equation: $F C M=M(0.4+0.15$ $\mathrm{F} \%$ ) Where $\mathrm{M}=$ milk yield, $\mathrm{F}=$ fat percentage.Milk fat percentage was determined according to Gerber's method as described by Ling (1963). Total solids percent (TS), total protein and ash were determined according to the standard methods of A.O.A.C. (1995). Lactose was determined according to a rapid method for the determination of lactose in milk and cheese described by John et al. (1957). Solid not fat (SNF) was calculated by the differences.

Data were statistically analyzed using the method of least squares analysis of variance using General Linear Models (GLM) procedure (SAS, 2000). Duncan's Multiple Range Test (Duncan, 1955) was used to compare among means of each trait.

\section{RESULTS AND DISCUSSION}

The nutrient composition of whole corn silage (WCS) before ensiling is shown in (Table 1). The dry matter (DM) content in whole corn plant before ensiling was $31.59 \%$ and decreased after ensiling (Table 2). The reduction of DM between before and after ensilage might be due to the fermentation process reported by Phillips et al (1981). The decreased DM was less with formic acid than control or bacterial inoculants silage. Similar results were reported by Rowghani and Zamiri. (2009) Crude protein (CP) content was affected by silage additives and was higher with silage treated with formic acid than silage inoculants or silage without additive. The higher CP content might be due to the restriction of fermentation, deamination and decarboxylation of proteins during ensilage Rooke et al., (1998). In general the chemical composition and physical characteristices of treated or untreated whole corn silage indicated that all silages were of good quality. These results did not differ than obtained by EL- Shinnawy (2003). Fresh WCS had higher content of NDF and ADF than after ensiling. These decreases in NDF and ADF content may have resulted from increased cell wall digestion due to increased silage fermentation. Also, inoculants silage was more affected on NDF, ADF, ADL and CF contents than the silage without additive and formic acid silage. These results were in-agreement with those obtained Ozkose et al., (2009) who found lowered NDF and ADF content of inoculants-treated silage than before ensiling Baytok et al. (2005) found that the crude fiber content, NDF and ADF were lower in all corn silages compared to corn before ensiling. While, in some studies formic acid treatment slightly decreased the ADF concentration in the silage through a rapid decrease of pH Marshall et al., (1993). However, in other studies formic acid treatment had no effect on cell wall degradation Nadeau et al., (2000). Data for Silage quality in terms of $\mathrm{pH}$, organic acids and $\mathrm{NH}-\mathrm{N}$ concentrations are presented in Table 2. All silages had a pH less than 4.2 indicating successful preservation and fermentation EL-Shinnawy (2003). The 
major fermentation product in all silages was lactic acid. Formic acid silage had lower $(P<0.05)$ lactic acid than inoculants silage and silage without additive. These results were in-agreement with Many researchers who have reported that addition of formic acid into silage decreased silage lactic acid content by limiting silage fermentation and reduction in organic acid (Kennedy, 1990); while bacterial inoculants silage had positive effects on lactic acid levels and total volatile fatty acids (VFA's) (Sanderson, 1993). When major bacterial population is lactic acid bacteria (LAB), fermentation products are mainly high levels of lactic acid, and low levels of acetic acid. In general these results indicated that, the lactic acid ranged between 3.92$4.9 \%$ DM which is the range of good quality silage (McDonald et al.1995) and EL-Shinnawy (2011). Silage NH3-N concentration, which reveals the extent of proteolysis in silage, was significantly $(P<0.05)$ lower with formic acid silage than inoculants silage and silage without additive. Sarah et al (1992) reported that formic acid was more consistent than bacterial inoculants in reducing protein degradation and de-amination in clover silage. Davies et al, (1998). Found that formic acid treatment reduced proteolysis during ensilage, whereas McDonald et al. (1995) reported that the concentration of NH3-N as $\%$ DM of a good quality silage should be less than $10 \%$ as $\%$ of total $\mathrm{N}$.

Table(3):Chemical composition of the experimental rations fed to animals.

\begin{tabular}{|l|c|c|c|c|c|c|}
\hline Item & OM & CP & CF & EE & NFE & Ash \\
\hline Control $^{*}$ & 91.88 & 12.88 & 17.19 & 3.09 & 58.72 & 8.12 \\
\hline $\mathrm{R}^{* \star}$ & 91.92 & 13.09 & 16.95 & 3.06 & 58.82 & 8.08 \\
\hline $\mathrm{R}^{* \star *}$ & 91.88 & 13.22 & 17.23 & 3.05 & 58.38 & 8.12 \\
\hline
\end{tabular}

Control ration $* 600 \mathrm{gCFM}+1500 \mathrm{~g}$ untreated corn silage.

Ration $1^{\star *}: 600 \mathrm{~g}$ CFM $+1500 \mathrm{~g}$ treated corn silage with inoculants.

Ration2 $^{\star \star \star}$ : $600 \mathrm{~g} \mathrm{CFM}+1500 \mathrm{~g}$ treated corn silage with formic acid.

Table (4): Digestibility coefficients (\%), nutritive values (\%) and nitrogen utilization of experimental rations fed to sheep (Mean $\pm \mathrm{SE}$ ).

\begin{tabular}{|c|c|c|c|}
\hline Item & Control & R1 & R2 \\
\hline \multicolumn{4}{|c|}{ Digestibility coefficients } \\
\hline DM & $67.80 \pm 0.88^{\mathrm{ab}}$ & $68.73 \pm 0.72^{\mathrm{a}}$ & $67.56 \pm 0.86^{\mathrm{ab}}$ \\
\hline OM & $70.60 \pm 0.74^{a b}$ & $71.73 \pm 0.79^{a}$ & $71.02 \pm 0.88^{a}$ \\
\hline $\mathrm{CP}$ & $64.45 \pm 0.47^{c}$ & $65.54 \pm 0.41^{\mathrm{b}}$ & $66.97 \pm 0.51^{a}$ \\
\hline $\mathrm{CF}$ & $60.69 \pm 0.66^{b}$ & $63.14 \pm 0.95^{a}$ & $60.95 \pm 0.84^{b}$ \\
\hline EE & $78.55 \pm 0.43$ & $78.17 \pm 0.82$ & $78.21 \pm 0.42$ \\
\hline NFE & $73.14 \pm 0.61^{b}$ & $74.65 \pm 0.48^{a b}$ & $75.25 \pm 0.29^{a}$ \\
\hline \multicolumn{4}{|c|}{ Nutritive value } \\
\hline TDN & $67.14 \pm 0.59^{b}$ & $68.57 \pm 0.62^{a}$ & $68.65 \pm 0.65^{a}$ \\
\hline DCP & $8.30 \pm 0.19^{a b}$ & $8.58 \pm 0.14^{a}$ & $8.85 \pm 0.17^{a}$ \\
\hline \multicolumn{4}{|c|}{ Nitrogen utilization } \\
\hline $\mathrm{NI}$ & $21.36 \pm 0.47^{b}$ & $21.98 \pm 0.42^{a b}$ & $22.60 \pm 0.39^{a}$ \\
\hline ND & $14.14 \pm 0.16^{\mathrm{b}}$ & $15.07 \pm 0.17^{a}$ & $15.35 \pm 0.12^{a}$ \\
\hline Urinary $\mathrm{N}$ & $7.70 \pm 0.26^{\mathrm{ab}}$ & $8.24 \pm 0.21^{a}$ & $8.29 \pm 0.29^{a}$ \\
\hline NB & $6.44 \pm 0.19^{b c}$ & $6.83 \pm 0.17^{b}$ & $7.06 \pm 0.13^{a}$ \\
\hline $\mathrm{NB} / \mathrm{NI}$ & $30.15 \pm 0.22^{b}$ & $31.10 \pm 0.17^{a}$ & $31.24 \pm 0.29^{a}$ \\
\hline NB/ND & $45.54 \pm 0.18^{\mathrm{ab}}$ & $45.32 \pm 0.29^{b}$ & $46.00 \pm 0.11^{a}$ \\
\hline
\end{tabular}

abc Means within the same rows with different superscript are significantly differ $(\mathrm{P}<0.05)$. 
Soliman, M. S.

The digestibility trails, nutritive values and nitrogen utilization are presented in table (4).The results indicated that animals fed R1 containing inoculants silage showed highest digestibility values of $D M, O M$, and $E E$ than control and R2 without significant difference. The digestibility of crude protein was significantly higher $(\mathrm{P}<0.05)$ with ration containing formic acid silage than control and R2. The observation that formic acid-based additives resulted in higher CP digestibility was in-agreement with those reported by Adesogan and salawu (2002), Hetta et al (2003). The effect of formic acid on CP digestibility could be due to reduced nitrogen losses through fermentation during ensilage. The digestibility of crude fiber was significantly higher with R1 containing inoculants silage compared to other rations. Knight et al. (2007) concluded that the degree of improvement in digestibility of crude fiber may have been due to increased silage fermentation caused by inoculants additives to silage. Bacterial inoculants also have been reported to affect fiber concentration and digestibility of silage fiber Harrison et al., (1989)

The nutritive value of the experimental rations expressed as (TDN \%) and (DCP \%) are presented in table 4 . The results indicated that, total digestible nutrient $(\% T D N)$ were higher $(P<0.05)$ for rations containing formic acid silage and inoculants silage than control ration. No significant differences $(P<$ 0.05 ) among rations for digestible crude protein (DCP \%), were recorded.

Nitrogen intakes, nitrogen balance for sheep fed the experimental rations are presented in table (4). The results showed that nitrogen intakes for sheep given experimental rations ranged from 21.36 to $22.60 \mathrm{~g} / \mathrm{h} /$ day. Also, these results indicated that all animals were in positive nitrogen balance (NB). Ration2 recorded significantly $(\mathrm{P}<0.05)$ higher NB value compared to control and $\mathrm{R} 1$. Increased $\mathrm{N}$ retention has been reported in sheep and dairy heifers fed silage treated with formic acid Sarah et al (1992). This increase in $\mathrm{N}$ retention appeared to be related to an improved $\mathrm{N}$ digestion as opposed to a reduction in urinary $\mathrm{N}$ excretion as reported by (McAllister et al., (1998). In the present study the differences in $\mathrm{N}$ digestion among experimental rations could be explained on the basis of ammonia levels in the silage Nkosi et al, (2010). According to McDonald et al. (1991), formic acid has been shown to reduce proteolysis in silage and increased protein digestion.

Table (5): Overall mean with their $\pm S E$ of rumen parameters of sheep fed the experimental Rations.

\begin{tabular}{|l|c|c|c|}
\hline \multirow{2}{*}{ Items } & \multicolumn{3}{|c|}{ Experimental rations } \\
\cline { 2 - 4 } & Control & $\mathbf{R 1}$ & $\mathbf{R 2}$ \\
\hline $\mathrm{pH}$ & $6.68 \pm 0.21$ & $6.61 \pm 0.20$ & $6.59 \pm 0.15$ \\
\hline $\begin{array}{l}\mathrm{NH}_{3}-\mathrm{N} \text { concentration } \\
(\mathrm{mg} / 100 \mathrm{mIR} . \mathrm{L})\end{array}$ & $9.74 \pm 0.32^{\mathrm{ab}}$ & $9.52 \pm 0.28^{\mathrm{ab}}$ & $10.12 \pm 0.26^{\mathrm{a}}$ \\
\hline $\begin{array}{l}\text { TVFA concentration } \\
\text { (meq/100 mIR.L) }\end{array}$ & $10.25 \pm 0.63^{\mathrm{b}}$ & $11.37 \pm 0.67^{\mathrm{a}}$ & $11.44 \pm 0.71^{\mathrm{a}}$ \\
\hline Acetic acid, \% & $60.68 \pm 0.31^{\mathrm{a}}$ & $57.37 \pm 0.29^{\mathrm{b}}$ & $58.49 \pm 0.36^{\mathrm{b}}$ \\
\hline propionic acid, \% & $18.33 \pm 0.19^{\mathrm{b}}$ & $20.62 \pm 0.11^{\mathrm{a}}$ & $19.97 \pm 0.18^{\mathrm{ab}}$ \\
\hline Butyric acid, \% & $13.80 \pm 0.23$ & $13.70 \pm 0.25$ & $13.30 \pm 0.17$ \\
\hline Acetic /propionic ratio & $3.31 \pm 0.05^{\mathrm{a}}$ & $2.78 \pm 0.04^{\mathrm{b}}$ & $2.92 \pm 0.05^{\mathrm{ab}}$ \\
\hline Microbial protein synthesis & $47.01 \pm 0.85^{\mathrm{a}}$ & $45.85 \pm 0.61^{\mathrm{b}}$ & $46.36 \pm 0.64^{\mathrm{b}}$ \\
\hline
\end{tabular}

${ }^{\text {ab }}$ means in the same row with different superscripts are significantly differ $(P<0.05)$. 
Rumen fluid fermentation parameters are showed in table (5). The results showed no-significant differences among $\mathrm{R} 1, \mathrm{R} 2$ and control ration in the value of rumen $\mathrm{pH}$, the rumen $\mathrm{pH}$ was not affected by the experimental rations, probably due to the buffering capacity of saliva reported by Jonas and Vilma (2006). The higher values for rumen ammonia- $\mathrm{N}$ concentration (mg/ $100 \mathrm{ml} \mathrm{R.L.)} \mathrm{recorded} \mathrm{with} \mathrm{sheep} \mathrm{fed} \mathrm{formic} \mathrm{acid} \mathrm{silage} \mathrm{were} \mathrm{not}$ statistically significant with those fed the control ration. These results were in agreement with those of Cao et al (2011) who reported that lactic acid bacteria ( $L A B$ ) inoculants improve the proteolysis of silage. Free amino acids and other products of protein hydrolysis are degraded very rapidly in the rumen which might increase concentration of ruminal ammonia- $\mathrm{N}$ at the first hour. The values of rumen total volatile fatty acids (VFA's) concentrations (m.eq/ $100 \mathrm{ml} \mathrm{R.L.)} \mathrm{of} \mathrm{sheep} \mathrm{fed} \mathrm{the} \mathrm{experimental} \mathrm{rations} \mathrm{are} \mathrm{presented} \mathrm{in}$ Table (5). Rations containing either formic acid silage or inoculants silage showed an increase in TVFA's concentrations without significant differences. But, Lower $(P<0.05)$ TVFA's concentrations obtained for control ration. These results were in-agreement with Jonas and Vilma (2006) who reported that sheep fed inoculated or chemically treated silages tended to have a higher $(\mathrm{P}<0.05)$ TVFA's compared with those fed untreated silage. Similar results obtained with by ziw (2003) who suggest that increased TVFA's occurred due to improvement of DM or OM digestibility. Percentage of acetic acid was higher $(P<0.05)$ in the rumen fluid of sheep fed control ration compared with the rumen fluid of sheep fed inoculants silage or formic acid silage. However, a percentage of propionic acid was greater in rumen fluid of sheep fed R1 than R2. While, percentage of propionic acid in rumen fluid of sheep fed control ration recorded lowest values $(P<0.05)$ compared with those fed R1. Probably lactic acid of silage was transformed into propionate in rumen. Dawson and Mayne (1997). The present study showed that the inoculants silage recorded highest value of lactic acid and also showed similar results with formic acid silage.

Table (6): Degradation kinetics of DM and CF for sheep fed the experimental rations (mean $\pm \mathrm{SE}$ ).

\begin{tabular}{|c|c|c|c|}
\hline Items & $\begin{array}{c}\text { Untreated Control } \\
\text { silage }\end{array}$ & $\begin{array}{c}\text { Inoculants Treated } \\
\text { silage }\end{array}$ & $\begin{array}{c}\text { Formic acid Treated } \\
\text { silage }\end{array}$ \\
\hline \multicolumn{4}{|c|}{ DM } \\
\hline$a \%$ & $24.05 \pm 0.42^{\mathrm{c}}$ & $27.37 \pm 0.54^{\mathrm{a}}$ & $25.94 \pm 0.63^{b}$ \\
\hline $\mathrm{b} \%$ & $53.01 \pm 0.73^{a}$ & $51.41 \pm 0.72^{\mathrm{b}}$ & $50.34 \pm 0.76^{c}$ \\
\hline $\mathrm{c} \%$ & $0.063 \pm 0.003^{c}$ & $0.064 \pm 0.001^{b}$ & $0.066 \pm 0.002^{a}$ \\
\hline \begin{tabular}{|l} 
EDDM, \% \\
\end{tabular} & $51.20 \pm 0.89^{b}$ & $53.91 \pm 0.53^{\mathrm{a}}$ & $52.31 \pm 0.83^{\mathrm{ab}}$ \\
\hline \multicolumn{4}{|c|}{$\mathrm{CF}$} \\
\hline$a \%$ & $21.56 \pm 0.32^{\mathrm{c}}$ & $24.59 \pm 0.22^{\mathrm{a}}$ & $22.70 \pm 0.24^{b}$ \\
\hline b \% & $52.77 \pm 0.21^{\mathrm{c}}$ & $57.18 \pm 0.25^{a}$ & $55.08 \pm 0.27^{\mathrm{ab}}$ \\
\hline $\mathrm{c} \%$ & $0.075 \pm 0.001^{b}$ & $0.072 \pm 0.001^{c}$ & $0.078 \pm 0.002^{\mathrm{a}}$ \\
\hline EDCF, \% & $50.87 \pm 0.37^{c}$ & $55.78 \pm 0.21^{a}$ & $53.83 \pm 0.13^{b}$ \\
\hline
\end{tabular}

abc Means within column with different superscript are significantly differ $(P<0.05)$. $\mathrm{a}=$ soluble fraction $(\%)$. $\mathrm{c}=$ rate of degradability $\left(\% \mathrm{~h}^{-1}\right)$.

b = potentially degradable fraction (\%).

$E D=$ effective degradability (\%) 
Soliman, M. S.

Microbial protein syntheses in the rumen of sheep fed the experimental rations are presented in table (5). The result showed that microbial protein synthesis was higher $(\mathrm{P}<0.05)$ for sheep fed control ration. On the other hand there were no significant differences in microbial protein synthesis between R1 and R2 containing inoculants silage and formic acid silage respectively. These results are in-agreement with results obtained by (Hoover and Stokes, 1991).

The effect of additives bacterial inoculants or formic acid on the degradation fractions and effective degradability (ED) of DM for experimental rations are shown in Table (6). Ration containing inoculants silage showed the highest rapid degradable fraction (a) followed by ration containing formic acid silage. Ration containing silage without additive had the lowest value $(P<0.05)$. However ration containing silage without additive recorded the highest potential degradable fraction (b) followed by ration containing inoculants silage. Ration containing formic acid silage had lowest value $(P<0.05)$. Similar trend has been recorded with degradation fractions of $C F$ these results were in agreement with those of Nowak et al (2004) who suggested that extensive silage fermentation may increase fraction (a) and reduce fractions (b). On the other hand ration containing inoculants silage recorded highest value ED of DM and CF followed by ration containing formic acid silage, while ration containing un-treated recorded lowest value $(P<0.05)$. These results are in agreement with those obtained by Filya et al (2002) who found that LAB mixture inoculant "A" $\{S$. faecium, L. plantarum, $P$. acidilactici\} reduced cell-wall contents and improved in situ rumen dry matter, organic matter, NDF and ADF degradability of the forage silages. Filya (2003) studied the effect of $L$. buchneri, alone, $L$. plantarum, alone or incombination with $L$. buchneri + L. plantarum on the ruminal degradability of corn and sorghum silages. Their results indicated increased of in situ rumen dry matter, organic matter and neutral detergent fiber degradability corn and sorghum silages. Yahaya et al. (2004) found that a lactic acid bacteria treatment increased degradability of dry matter and NDF significantly and Nowak et al. (2004) found that formic acid slightly but not significant increased in ruminal DM degradability of grass silage compared with inoculants.

Table (7): Milk yields and milk composition of lactating cows fed the experimental rations (mean $\pm S E$ ).

\begin{tabular}{|l|c|c|c|}
\hline \multirow{2}{*}{ Item } & \multicolumn{3}{|c|}{ Experimental rations } \\
\cline { 2 - 4 } & Control ration & $\mathbf{R 1}$ & $\mathbf{R 2}$ \\
\hline Milk yields kg/d & $13.36 \pm 0.70^{\mathrm{b}}$ & $14.87 \pm 0.85^{\mathrm{a}}$ & $14.62 \pm 0.76^{\mathrm{a}}$ \\
\hline $4 \% \mathrm{FCM}$ & $12.65 \pm 0.82^{\mathrm{b}}$ & $14.40 \pm 0.74^{\mathrm{a}}$ & $14.05 \pm 0.71^{\mathrm{a}}$ \\
\hline Fat, kg/d & $0.49 \pm 0.02^{\mathrm{bc}}$ & $0.56 \pm 0.01^{\mathrm{a}}$ & $0.54 \pm 0.02^{\mathrm{b}}$ \\
\hline \multicolumn{3}{|c|}{ Milk composition $(\%):$} \\
\hline Total solids & $12.67 \pm 0.32^{\mathrm{ab}}$ & $12.95 \pm 0.33^{\mathrm{a}}$ & $13.00 \pm 0.58^{\mathrm{a}}$ \\
\hline Solids not fat & $9.02 \pm 0.27^{\mathrm{c}}$ & $9.16 \pm 0.41^{\mathrm{b}}$ & $9.26 \pm 0.49^{\mathrm{a}}$ \\
\hline Fat & $3.65 \pm 0.18^{\mathrm{b}}$ & $3.79 \pm 0.16^{\mathrm{a}}$ & $3.74 \pm 0.13^{\mathrm{a}}$ \\
\hline Protein & $3.42 \pm 0.25^{\mathrm{b}}$ & $3.54 \pm 0.34^{\mathrm{a}}$ & $3.58 \pm 0.28^{\mathrm{a}}$ \\
\hline Lactose & $4.68 \pm 0.15$ & $4.71 \pm 0.18$ & $4.75 \pm 0.13$ \\
\hline Ash & $0.92 \pm 0.01$ & $0.91 \pm 0.02$ & $0.93 \pm 0.01$ \\
\hline
\end{tabular}

abc Means within rows with different superscript are significantly differ $(P<0.05)$. 
Data for the daily milk and FCM (4\%) production are presented in table (7): In general, cows fed on rations containing either corn silage treated with inoculants or treated with formic acid had the highest $(P<0.05)$ daily milk yield and 4\% FCM yield, while, cows fed the control ration recorded the lowest milk yield and 4\% FCM yield. These results were in-agreement with those of Mayne and Steen (1993) who found that the use inoculants or formic acid as additive silage increase $(P<0.05)$ milk yield, FCM yield and milk protein than the untreated silage. Glenn et al. (1986) reported a trend for higher milk yields when cows were fed alfalfa silage treated with formic acid. $\mathrm{He}$ also, found that milk production from direct-cut formic acid silage was greater than that obtained from untreated direct-cut silage. Indeed, several studies have reported improved milk yield by lactating dairy cows feeding silage treated with inoculants (Zwi 2003 Selmar-Olsen and Mo, 1997and Kennedy 1990). On the other hand Peymanfar and Kermanshahi (2012) stated that increasing of feed intake; fiber degradation and digestibility of nutrients have impact on improvement milk yield and milk composition. Milk compositions (\%) of cows fed the experimental rations are showed in table (7) Cows fed ration containing silage treated with inoculants had almost higher $(P<0.05)$ milk components $(\%)$ and fat yield $(\mathrm{g} / \mathrm{d})$. No significant differences $(P<0.05)$ were found for milk lactose $(\%)$ among rations. These results indicated that either treatment with inoculants or with formic acid improved the milk yield, $4 \%$ FCM milk composition (\%) and yields (g/d) for cows fed these rations. In general effects of silage additives on cattle included increased silage intake, Zwi (2003) increased milk yield (Gordon, 1989) and improved milk composition (Selmar-Olsen and Mo, 1997).

Table (8): Economic efficiency for lactating cows fed the experimental rations (mean $\pm \mathrm{SE}$ ).

\begin{tabular}{|l|c|c|c|}
\hline Item & Control ration & R1 & R2 \\
\hline Silage intake $\mathrm{kg} / \mathrm{h} /$ day & 17.00 & 18.700 & 18.500 \\
\hline CFM intake $\mathrm{kg} / \mathrm{h} /$ day & 6.00 & 6.00 & 6.00 \\
\hline Silage DM intake kg/h/day & $5.00 \pm 0.54^{\mathrm{c}}$ & $5.60 \pm 0.67^{\mathrm{ab}}$ & $5.74 \pm 0.62^{\mathrm{a}}$ \\
\hline CFM DM intake $\mathrm{kg} / \mathrm{h} /$ day & 5.532 & 5.532 & 5.532 \\
\hline Total DM intake $\mathrm{kg} / \mathrm{h} /$ day & $10.500 \pm 0.75^{\mathrm{bc}}$ & $11.100 \pm 0.77^{\mathrm{ab}}$ & $11.240 \pm 0.72^{\mathrm{a}}$ \\
\hline Cost of total feed/LE/h/day & 22.47 & 23.90 & 23.97 \\
\hline Price of milk yield(LE) & 63.25 & 72.00 & 70.30 \\
\hline Net revenue & 30.97 & 48.38 & 46.30 \\
\hline Economic Efficiency\% & 181.48 & 201.25 & 193.28 \\
\hline
\end{tabular}

abc Means within rows with different superscript are significantly differ $(\mathrm{P}<0.05)$.

Free market prices (LE/ton) for the whole silage corn $=510 \mathrm{LE}$

Free market prices (LE/ton) for the inoculants treated whole silage corn $=540$

Free market prices (LE/ton) for the formic acid treated whole silage corn $=550$

Free market prices (LE/ton) for CFM = $2300 \mathrm{LE}$

Free market prices (LE/kg) for milk yield $4 \%$ fat $=5$ LE

The DM silage intake silage in terms of, CFM and economic evaluations of the different rations treated are presented in Table (8). Dry matter intake was insignificantly higher for cows fed silage treated with formic acid than inoculated treated. These results may be due to increase dry matter 
Soliman, M. S.

in silage treated with formic acid than inoculants. While, cows fed un-treated silage recorded the lowest $(P<0.05) D M$ silage intake. These results were inagreement with Petterson et al., (1997) who found that DM intake increased with silage containing lower percentage of acetic acid. Many studies have been reported a positive effect of formic acid and bacterial inoculants on increased silage intake and a beneficial effect on cattle performance Zwi (2003).

The economic efficiency\% was higher for the cows fed silage treated with inoculants flowed formic acid treated and lower recorded with un-treated silage. Hafez et al (2012) indicated that feed cost to produce one $\mathrm{Kg}$ gain was less for lambs fed inoculated corn silage compared with un-inoculated and improved economic efficiency. Abido et al (2007) stated that using inoculated maize silage improved economic efficiency for lactating buffaloes.

\section{CONCLUSION}

The addition of the inoculants or formic acid to WCS improved the quality of silage while formic acid reduced losses of nitrogen and increased of CP during ensilage which improved CP digestibility and NB. While, inoculants increased lactic acid and reduced of NDF that are impact to improved CF digestibility. So addition of the inoculants or formic acid to WCS led to positive improved in palatability of WCS silage and resulted in a higher $(\mathrm{P}<$ 0.05) intake of treated silage by crossbred Friesian cows, in addition to increased production, milk composition and economic efficiency. Further works is needed on making silage from residues and determine the optimum levels of silage additives to be used on other kinds of animals and on various types of production.

\section{REFERENCES}

A.O.A.C. (1995). Multiresidue method (16 th Ed. 985.22) Association Official Analytical Chemists. Washington, Virginiall, U.S.A.

Abido, A.M. H.S. Soliman, Akila S. Hamza, S.M. Kholif, H.M. Elsayed and A.S. Abd-Elaziz , (2007). Effect of maize silage Inoculated by Bacteria on performance of lactating buffaloes. International Journal of Dairy Science, 2: 330-338.

Adesogan, A. T. and S. B. Salawu. 2002. The effect of different additives on the fermentation quality, aerobic stability and in vitro digestibility of pea/wheat bi-crop silages containing contrasting pea to wheat ratios. Grass Forage Sci. 57:25-32.

Adesogan, AT and MB Salawu, (2004). Effect of applying formic acid or Lactobacillus buchneri inoculants with or without homofermentative lactic acid bacteria on thefermentation characteristics and aerobic stability of intercropped pea-wheat silages and whole crop wheat or pea silages. J. Sci.Food Agric., 84: 983-992. 
Adesogan, AT; SC Kim; Arriole KG; DB Dean, and CR Staples, (2007). Strategic addition of dietary fibrolytic enzymes for improved performance of lactating dairy cows. Proceedings of 18th annual Florida ruminant nutrition. Symposium, Gainesville, Florida. PP: 92110.

Al-Rabbat, M.F., R.L. Baldwin and W.C. Weir, (1971). In vitro nitrogen-treacer technique for some kinetic measures of rumen ammonia. J. Dairy Sci., $54,150$.

AOAC, 1990. Official Methods of Analysis. 15th ed. Association of Official Analytical Chemists, Washington D.C., USA.

Barney Harris jr,(1992). Nutrient Requirements of Dairy Cattle. This document is Fact Sheet DS 38, of the Dairy Production Guide, originally published as part of Circular 594, Florida Cooperative Extension Service.

Baytok, E., T. Aksu, M. A. Karsli and H. Muruz. 2005. The effects of formic acid, molasses and inoculant as silage additives on corn silage composition and ruminal fermentation characteristics in sheep. Turk. J. Vet. Anim. Sci. 29:469-474.

Bill Seglar, D.V.M., (2003) Global Agronomy and Nutritional Sciences 7100 N.W. $62^{\text {nd }}$ Ave., Box 1150 Johnston, IA 50131-1150.

Bosch, MW; , SCW Lammers-Wienhoven; GA Bangma, and H Boer, (1991). Influence of stage of maturity of grass silages on digestion processes in dairy cows. 2. Rumen contents and ruminal passage rates. Wageningen., P: 33.

Bosch, MW; SCW;Lammers-Wienhoven, GA Bangma, and H Boer, (1991). Influence of stage of maturity of grass silages on digestion processes in dairy cows. 2. Rumen contents and ruminal passage rates. Wageningen., P: 33.

Burns. (1991). Silage production in Tennessee.University of Tennessee Agricultural Exten Service.

Bush, K.J., R.W. Russel and J.W. Young (1979). Quantitative separation of volatile fatty acids by high performance liquid chromatography. J. Liquid Chromatography.

Cao, Y., Cai Y., T.Takahashi , N. Yoshida, M. Tohno, Uegaki, R. K.Nonaka, and F.Terada, (2011). Effect of lactic acid bacteria inoculant and beet pulp addition on fermentation characteristics and in vitro ruminal digestion of vegetable residue silage. Journal of Dairy Science, Vol. 94, No. 8, (March 2011), pp. 3902-3912, ISSN 0022-0302.

Carrol, E.J. and R.E. Hungate, (1954). The magnitude of microbial fermentation in the bovine rumen. Appl. Microbiol., 2: 205.

Davies, D.R., R.J., Merry, A.P.,Willams, E.L., Bakewell, D.K. Leemans, and J.K.S., Tweed, 1998. Proteolysis during ensilage of forages varying in soluble sugar content. J. Dairy Sci. 81, 444-453.

Dawson, L.E.R., C.S., Mayne, 1997. The effect of infusion of putrescine and gamma amino butyric acid on theintake of steers offered grass silage containing three levels of lactic acid. Anim. Feed Sci.Technol.66,15-29. 
Soliman, M. S.

Driehuis, F., S.J.W.H. Oude Elferink, and P.G., Van Wikselaar, (2001). Fermentation characteristics and aerobic stability of grass silage inoculated with Lactobacillus buchneri, with or without homofermentative lactic acid bacteria. Grass Forage Sci. 56, 330-343.

Duncan, D.B. (1955). Multiple ranges and multiple F- test. Biometric, 11: 142.

EL- Shinnawy, A.M., 2003, Studies on silage in ruminants feeding M.sc.Thesis. Fac. of Agric. Cairo Univ. Egypt.

El- Shennawy,M.M., M.F. Emara, H.F.A.Maatwe, Fatma, M. Salman and A.M. EL- Shinnawy (2011) Effects of two kinds of bacteria inoculants on preservation and nutritive values of vine broad bean silages, compared with clover hay. proc of the 4 th. Animal wealth research conf.the Middle East \& North Africa.

El-Shazly, K. and R.E. Hungate, (1965). Fermentation capacity as measure of net growth of rumen microorganisms. Appl. Microbiol., 13: 62.

Filya, I (2003). The effect of Lactobacillus buchneri and Lactobacillus plantarum on the fermentation, aerobic stability, and ruminal degradability of low dry matter corn and sorghum silages. J. Dairy Sci., 86: 3575- 3581.

Filya, I; A Karabulut, and A Sucu, (2002). The effect of Lactobacillus plantarum and Lactobacillus buchneri on the fermentation, aerobic stability, and ruminal degradability of maize silage in warm climate. Proceedings of 13th international silage conference. Ayr, Scotland. PP: 192-193.

Gaines, W.L. (1923). Relation between percentage of fat content and yield of milk. 1. Correction of milk yield for fat content. Agric. Exo. Sta. Bull. 245 (C.F. Gaines, 1928).

Glenn, B. P., H. F. Tyrrell, D. R. Waldo, and H. K.Goerbg, 1986. Effects of diet nitrogen and forage nitrogen insolubility on performance of cows in early lactation. J. Dairy Sci. 69:2825.

Goering, H.K. and P.J. Van Soest, (1970). Forage fiber analysis (Apparatus, reagents and some application). Agric., Handbook No. 379. Agric. Res. Serv. USDA, Washington, D.C.

Gordon, F., 1989. An evaluation through lactating cattle of a bacterial inoculant as an additive for grass silage. Grass Forage Sci. 44, 169179.

Hafez,Y.H. A.A. Abedo and E.I.Khalifa (2012). Effect of microbial inoculation of whole plant corn silage on growth performance and carcass characteristics of rahmani lambs. Egyptian Journal of Sheep and Goat Sciences, Vol. 7 (2), P: 17-29.

Harrison, J. H., S. D. Soderlund, and K. A. Loney. (1989). Effect of inoculation rate of selected strains of lactic acid bacteria on fermentation and in vitro digestibility of grass-legume forage. J. Dairy Sci. 72:2421.

Hetta, M., J.W., Cone, A-M. Gustavsson, and K. Martinsson, (2003). The effect of additives in silages of pure timothy and timothy mixed with red clover on chemical composition and in vitro rumen fermentation characteristics. Grass nd Forage Science 58, 249-257. 
Hoover, W. H., and S. R. Stokes. 1991. Balancing carbohydrates and proteins for optimum rumen microbial yield. J. Dairy Sci. 74:36303644.

John,A.,G.Barnett and G.G.Abdel Tawab,(1957).A rapid method for determination of lactose in milk and cheese.J.Sci.Food Agric.,7:437441.

Jonas J. and V.Vilma (2006). Effects of silage fermentation quality on ruminal fluid parameters. BIOLOGIJA. 2006. Nr. 4. P. 65-71.

Kennedy, S.J., 1990. An evaluation of three bacterial inoculants and formic acid as additives for first harvest grass. Grass Forage Sci. 45, 281-288.

Knight, M.L., J.G. Linn and H.G. Jung, 2007. Effect of direct-fed microbials on performance, diet digestibility and rumen characteristics of holstein dairy cows. J. Dairy Sci., 90: 1802-1809.

Ling, E.R. (1963). A Text Book of Dairy Chemistry. $3^{\text {rd }}$ Ed., Vol. П. Chapman and Hall Ltd., London.

Marshall, S.A., C.P.Campbell, and J.G., Buchanan-Smith, 1993. Proteolysis and rumen degradability of alfalfa silages preserved with a microbial inoculant, spent sulfite liquor, formic acid or formaldehyde .Can. J. Anim. Sci. 73, 559-570.

Mayne, C. S. and R.W. J. Steen, (1993). Areview of animal production responses to formic acid and inoculant treatment of grass silage in trials at the Agricultural Research In stitute of Northern Ireland. Procee dings of the 10th International Silage Conference, Dublin, 178.

McAllister, T.A., R., Feniuk, Z., Mir, L.B. Selinger, and K.J., Cheng, (1998). Inoculants for alfalfa silage: Effects on aerobic stability, digestibility and the growth performance of feedlot steers. Livest. Prod. Sci. 53, 171181.

McDonald I. (1981). A revised model for the estimation of protein degradability in the rumen. J. Agric. Sci. 96: 251-252.

McDonald, P., A.R. Henderson, and S.J.E., Heron, (1991). The Biochemistry of Silage. Chalcombe Publications, Marlow, Buckinghamshire, UK. pp. 109.

McDonald, P., R.A. Edwards, J.F.D. Greenhalgh and C.A. Morgan (1995). Animal Nutrition. 5th Ed., Copyright Licensing LTD., London.

Mohamed, S.A., M.K. Mohsen, M.M. Bendary, E.M. Abdel-Raouf and H.M.A. Gaafar (2003). Performance of growing Friesian calves fed rations containing corn silage. 2- Blood constituents and carcass traits. Egyptian J, Nutrition and Feeds 6 (Special Issue): 727.

N.R.C (1990). Nutrient requirements of dairy cattle. $7^{\text {th }}$ Ed., National Academy of Sciences. National Research Council, Washington, D.C.

National Research Council. (1994). Nutrient Requirements of sheep, 9th Revised Edition, National Academy Press, Washington, DC.

Nadeau EMG, Buxton DR, Russell JR, Allison MJ, Young JW (2000). Enzyme bacterial inoculant and formic acid effects on silage composition of orchard grass and alfalfa. J. Dairy Sci 83:1487. 
Soliman, M. S.

Nkosi, B.D., R., H.J. Meeske, Van der Merwe, and I.B., Groenewald, (2010). Effects of homofermentative and heterofermentative bacterial silage inoculants on potato hash silage fermentation and digestibility in rams. Anim. Feed Sci. Technol. 157, 195-200.

Nowak, W., A.Potkański, and S., Wylegała, (2004). The effect of additives on quality, protein degradability, intestinal digestibility and feed intake of wilted grass silages. J. Anim. Feed Sci. 13, 101-100.

ÕKiely, P. (1993); Influence of a partially neutralised blend of aliphatic organic acid on fermentation, effluent production and aerobic Stability of Autumn Grass Silage. Irish J. Agric. Food Res., 32: 13-26.

Orskov, E.R. and I. McDonald. (1979).The estimation of protein degradation in the rumen from incubation measurements weighted according to rate of passage. Journal of agriculture Science Cambridge 92: 499.

Ozkose, E., Akyol, I., Kar, B., Comlekcioglu, U. \& Ekinci, M.S., 2009. Expression of fungal cellulose gene in Lactococcus lactis to construct novel recombinant silage inoculants. Folia Microbiol. 54, 335-342.

Petterson, D.C., C.S., Mayne, F.J. Gordon, and D.J., Kilpatrick, (1997). An evaluation of an inoculant/enzyme preparation as an additive for grass silage for dairy cattle. Grass Forage Sci. 52, 325-335.

Peymanfar S, and R. Kermanshahi . (2012). The effect of bacteria, enzymes and inulin on fermentation and aerobic stability of corn silage. Iran Microbiol. ;4(4):180-6.

Phillips, W. A. L. C. Pendlum and F. P. Horn. (1981). Ensiling of Whole Wheat Plant at Different Maturities and Dry Matter. Animal Science Research Report 106-107.

Randby AT. (1999). Effect of ethanol in feed on milk flavour and chemical composition. In: 12th International Silage Conference, Upsala: 205-6.

Rooke, JA; FM; Maya, J.A. Arnold, and DG Armstrong, (1998). The chemical composition and nutritive value of grass silages prepared with no additive or with the application of additives containing either Lactobacillus plantarum or formic acid. Grass Forage Sci., 43: 87-95.

Rowghani, E. and M. J. Zamiri, (2009) The effects of a microbial inoculant and formic acid as silage additives on chemical composition, ruminal degradability and nutrient digestibility of corn silage in sheep. Iranian Journal of Veterinary Research, Shiraz University, Vol. 10, No. 2, Ser. No. 27.

Russell, J.P. (1984) Factors influencing competitions and compositions of rumen bacterial flora. Proc. Symp. Herbivore Nutrition in Sub-Tropics and Tropics. The Science Press, Graighall, South Africa. P 313.

Sarah A. Nagel And Glen A. Broderick2 Sarah A. Nagel And Glen A. Broderick (1992) Effect of Formic Acid or Formaldehyde Treatment of Alfalfa Silage on Nutrient Utilization by Dairy Cows. J Dairy Sci 75:140154.

Sanderson,M.A.,(1993).Aerobic stability and in vitro fibre digestibility of microbially inoculated corn and sorghum silages. J.Anim. Sci.71,505514.

SAS (2000). SAS users guide: Statistics, SAS Inst., Inc., Cary N.C., USA. 
Selmar-Olsen, I. and M., Mo, (1997). The effects of three different silage additives on the extent of silage fermentation and the performance of dairy cows. Acta Agric. Scand. Sect. A-Anim. Sci. 47, 148-158.

Snyman, LD and HW Joubert, (1996). Effect of maturity stage and method of preservation on the yield and quality of forage sorghum. Anim. Feed Sci. Technol., 57: 63-73.

Van Soest P J. (1963). Use of detergents in the analysis of fibrous feeds. II. A rapid method for the determination of fiber and lignin. J. Ass. Offic. Agr. Chem. 46:829-35.

Waldo, D.R. and L.H. Schultz (1956). Lactic acid production in the rumen. J. Dairy Sci., 39: 1455.

Warner, A.C.I. (1964). Production of volatile fatty acids in the rumen methods of measurements. Nutr. Abstr. and Rev., 34:339.

Weinberg, ZG; G;Ashbell, KK; Bolsen, G;Pahlow, Y Hen, and A Azrieli, (1995). The effect of a propionic acid bacterial inoculant applied at ensiling, with or without lactic acid bacteria, on the aerobic stability of pearl millet and maize silages. J. Appl. Bacteriol., 78: 430-436.

Yahaya, M.S., M., W., Goto, W., Yimiti, W., Karita, B. Smerjai, and Y., Kawamoto, (2004). Additives effect of fermented juice of epiphytic lactic acid bacteria and acetic acid on silo fermentation and ruminal degradability of tropical elephant grass. J. Anim. Vet. Adv. 3, 116-122.

Ziw, G. W. (2003). Effect of lactic acid bacteria on animal performance. Indian Journal of Biotechnology. Vol2, 378-381. 
Soliman, M. S.

تأثير إضافة اللقاحات البكتيرية أوحض الفورميك لنبات الذرة الكامل على جودة السيلاج و الألئ القيمة الغذائية في الأغنام - إنتاج اللبن وتركيبة في الأبقار الحلابة التية

سليمان محمد سليمان

المركز الأقليمي للأغية والأعلاف، مركز البحوث الزراعية، وزارة الزراعة، مصر

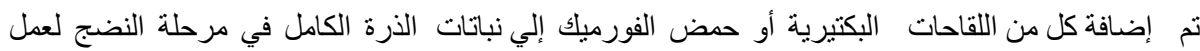

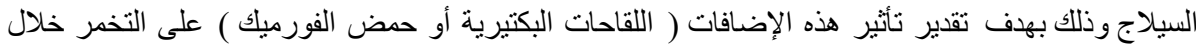

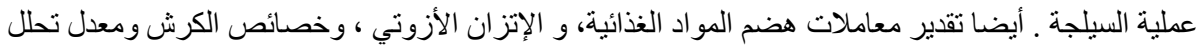

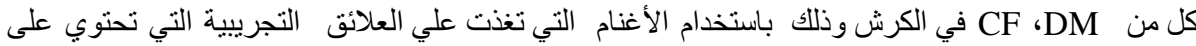

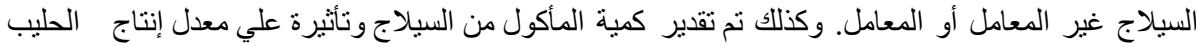

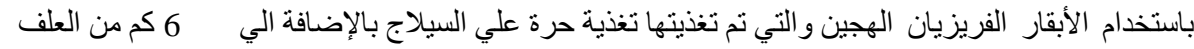

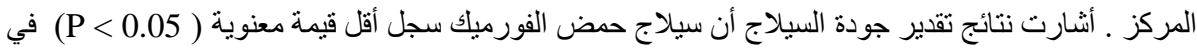

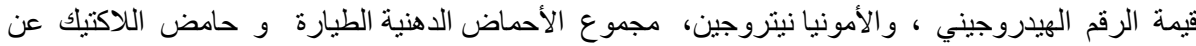

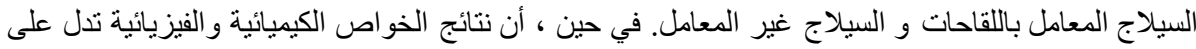

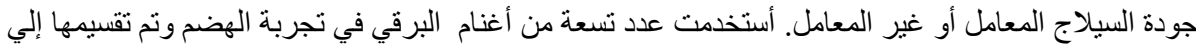

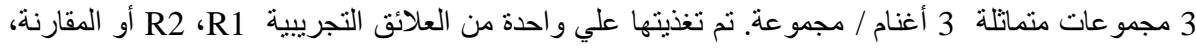

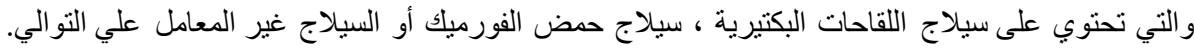

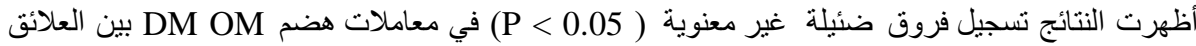

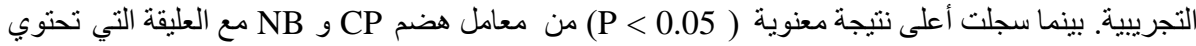

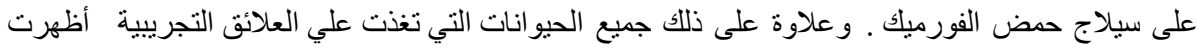

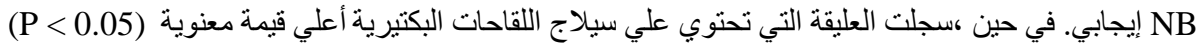

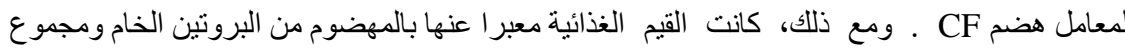

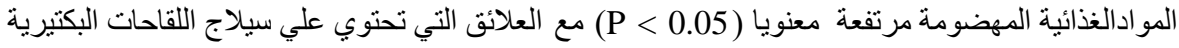

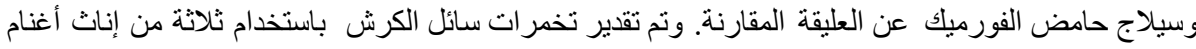

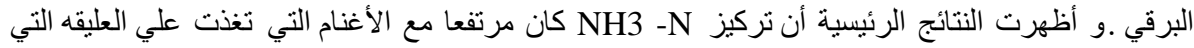

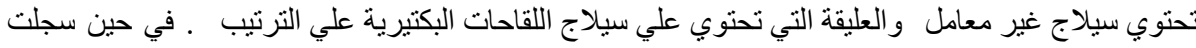

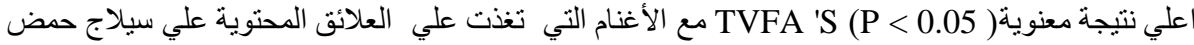

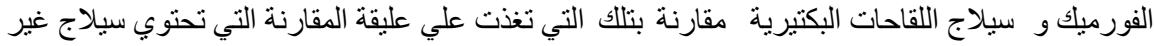

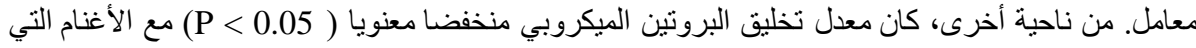

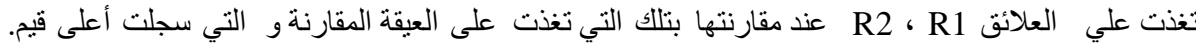
وأظهرت نتائج تحلل المادة الجافة و الألياف الخام زيادة معنوية (

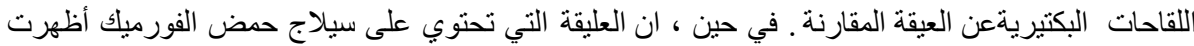

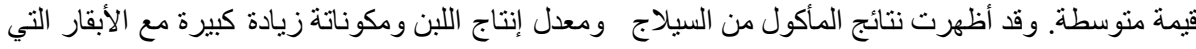

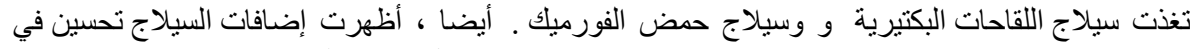

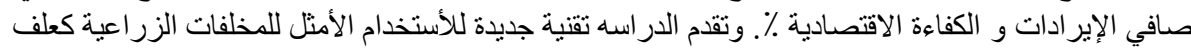
تعويضي في تغذية المجتر ات وتقليص مشاكل البيئه. 
J. Animal and Poultry Prod., Mansoura Univ., Vol. 5 (5), May, 2014 
Soliman, M. S. 